\title{
BRPKM
}
Buletin Riset Psikologi dan Kesehatan Mental http://e-journal.unair.ac.id/index.php/BRPKM e-ISSN: 2776-1851

ARTIKEL PENELITIAN

\section{Pengaruh Store Atmosphere dan Brand Image terhadap Perilaku Impulsive Buying Pada Konsumen Retail Fashion}

\author{
ANNISA SAVIRA ALIFIA \& CHOLICHUL HADI* \\ Fakultas Psikologi Universitas Airlangga
}

\begin{abstract}
ABSTRAK
Penelitian ini bertujuan untuk mengetahui pengaruh store atmosphere dan brand image terhadap impulsive buying pada konsumen retail fashion brand X di Surabaya. Penelitian ini dilakukan pada 130 partisipan yang melakukan pembelian produk fashion dalam kurun waktu 1 tahun terakhir di toko secara offline. Pengumpulan data dilakukan dengan menggunakan kuesioner skala store atmosphere yang terdiri dari 11 aitem, skala brand image yang terdiri dari 8 aitem, dan skala impulsive buying yang terdiri dari 9 aitem. Teknik analisis data dilakukan menggunakan analisis regresi linier menggunakan parangkat lunak IBM SPSS Statistics 22 for windows. Hasil penelitian menunjukkan bahwa tidak terdapat pengaruh antara store atmosphere terhadap impulsive buying secara parsial, terdapat pengaruh antara brand image terhadap impulsive buying secara parsial. Kemudian terdapat pengaruh yang signifikan antara variabel store atmosphere dan brand image secara simultan terhadap impulsive buying.
\end{abstract}

Kata kunci: brand image, impulsive buying, store atmosphere

\begin{abstract}
This study aims to determine effect of store atmosphere and brand image on impulsive buying of retail consumer fashion brand X in Surabaya. This research was conducted on 130 partisipants who made purchases of fashion products within the last 1 year at offline stores. Data collection was carried out using a store atmosphere scale consisting of 11 items, a brand image scale consisting of 8 items, and an impulsive buying scale consisting of 9 items. The data analysis technique was performed using linear regression analysis using IBM SPSS Statistics 22 for windows software. The results showed that there was no significant influence between store atmosphere on impulsive buying, and there was an impact between brand image and impulsive buying. Then there was a significant impact store atmosphere and brand image simultaneously on impulsive buying.
\end{abstract}

Key words: brand image, impulsive buying, store atmosphere

Buletin Penelitian Psikologi dan Kesehatan Mental (BRPKM), 2021, Vol. 1(1), 508-519

*Alamat kopartisipansi: Fakultas Psikologi Universitas Airlangga, Kampus B Universitas Airlangga Jalan Airlangga 4-6 Surabaya 60286. Surel: cholichul.hadi@psikologi.unair.ac.id

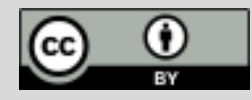

Naskah ini merupakan naskah dengan akses terbuka dibawah ketentuan the Creative Common Attribution License (CC-BY-4.0) (http://creativecommons.org/licenses/by/4.0), sehingga penggunaan, distribusi, reproduksi dalam media apapun atas artikel ini tidak dibatasi, selama sumber aslinya disitir dengan baik. 


\section{PENDAHULUAN}

Fashion adalah salah satu cara bagaimana seseorang menjalani kehidupan sehari-hari, seperti bagaimana cara berpakaian. Fashion memiliki sifat yang dinamis dan selalu berubah seiring berjalannya waktu. Fashion menjadi hal yang tiap orang lakukan di kehidupan sehari-hari mereka atau bisa dikatakan sebagai gaya hidup atau lifestyle (Mehta \& Sharma, 2013). Produk fashion adalah hasil dari proses produksi yang meliputi baju, celana, tas, sepatu, aksesoris lainnya yang dapat menunjang penampilan pemakainya. Fashion juga menjadi representasi visual dari ekonomi, politik ataupun budaya dari masyarakat pada waktu tertentu. Hal ini dapat dilihat dari kehidupan sehari-hari, buku, majalah, dan lain sebagainya (Ramadhan, 2017). Pertumbuhan dan perkembangan yang ada di dunia fashion terus berputar dan memiliki cycle sendiri sehingga produk fashion yang ada saat ini dapat berubah ditahun yang akan datang. Hal ini membuat bisnis fashion terus berkembang secara baik (Mehta \& Sharma, 2013). Dunia fashion mencakup banyak industri, dan salah satunya adalah industri pakaian.

Pada zaman sekarang, perusahan-perusahaan retail dalam bidang fashion sudah banyak mengeluarkan brand-brand fashion mereka di pasar global. Saat ini perusahaan retail sudah sangat menjamur dan menyebar di seluruh bagian dunia dikarenakan adanya perkembangan bisnis yang baik pada pasar fashion. Di Indonesia pun perusahaan retail lokal hingga internasional mencoba menguasai dan membuktikan bahwa produk dari brand fashion yang mereka tawarkan adalah yang terbaik kepada konsumen. Beberapa dari perusahaan retail fashion yang ada di pasaran terus melakukan inovasiinovasi yang sesuai dengan apa yang diminta oleh konsumen dan saling bersaing untuk mengeluarkan produk-produk mereka yang dapat menarik pembeli. Perkembangan retail modern menjadi salah satu pengaruh munculnya perilaku pembelian impulsif pada konsumen. Hasil studi Nielsen pada tahun 2011 menyatakan bahwa konsumen akan pergi ke pusat perbelanjaan untuk melakukan pembelian dan melampiaskan kejenuhannya. Banyaknya pusat perbelanjaan yang ada pada saat ini, membuat konsumen memiliki perubahan gaya hidup yang lebih konsumtif. Hal ini menjadi salah satu pengaruh munculnya perilaku impulsif pada konsumen (Kusuma, 2017).

Pembelian secara impulsif atau dapat disebut dengan impulsive buying adalah ketika muncul dorongan psikologis pada seseorang secara cepat untuk melakukan tindakan impulsif, seperti ketika seseorang hendak melakukan pembelian atas suatu produk secara spontan, sangat kuat dorongan yang muncul dan terjadi secara terus menerus (Rook D. W., 1987). Beatty \& Ferrell (1998) juga mendefinisikan pembelian secara impulsif sebagai pembelian secara tiba-tiba tanpa adanya niat berbelanja sebelumnya dan terjadi secara spontan dan tanpa adanya refleksi terlebih dahulu. Stern juga mengatakan bahwa pembelian impulsif pada umumnya adalah pembelian yang tidak ada perencanaan terlebih dahulu (Stern, 1962). Survei berkala yang dilakukan oleh supermarket dari divisi DuPont Company melakukan sebuah survei melalui metode pembeli ditanya setelah masuk dari toko dan apa yang ingin mereka beli dan akan diperiksa sebelum pembeli keluar. Survei ini menunjukkan bahwa pembeli membeli produk yang tidak mereka sebutkan diwawancara sebelumnya dan dapat dikatakan bahwa pembelian tersebut adalah termasuk pembelian tidak direncanakan atau pembelian impulsif. Menurut CNN Indonesia pada tahun 2015 yang diriset oleh Mastercard, menyatakan bahwa sebanyak 50\% generasi milenial atau usia produktif sekitar usia 18 hingga 29 tahun merupakan konsumen paling sering dalam melakukan pembelanjaan impulsif di Asia Pasifik (CNN, 2015). 
Rook (1987, dalam Bayley \& Nancarrow, 1998) membagi karakteristik impulsive buying menjadi lima hal, yaitu adanya perasaan yang meliputi ketika melihat suatu produk, munculnya perasaan yang intens untuk segera membeli produk yang dilihat, mengabaikan konsekuensi negatif yang dapat terjadi setelah pembelian produk, diikuti oleh perasaan senang, dan adanya konflik antara kontrol dalam pembelian. Impulsive buying dapat terjadi dikarenakan kurang adanya perencanaan dan pertimbangan terlebih dahulu mengenai pembelian pada suatu produk. Hal ini dapat terjadi apabila pembelian akan suatu produk sebenarnya telah direncakanan lama sebelumnya atau sering melakukan pembelian secara berulang atau menjadi sebuah kebiasaan (Verplanken \& Aarts, 1999). Perilaku impulsif juga dapat memberikan dampak yang muncul akibat dari perilaku ini. Pembelian secara impulsif memiliki dampak bagi seseorang yang melakukannya. Dampak yang muncul adalah adanya respon emosi positif dan negatif. Respon emosi positif yang muncul pada konsumen yaitu sebelum membeli, saat membeli ataupun setelah melakukan pembelian seperti kesenangan dan kegembiraan. (Dittmar \& Drury, 2000). Respon negatif juga dapat muncul dikarenakan ketika konsumen merasakan adanya dorongan untuk membeli sangat kuat sehingga dalam beberapa situasi konsumen akan merasakan frustasi karena tidak bisa menolak keinginan untuk membeli. Apabila hal ini terus menerus dilakukan akan memunculkan keinginan kuat untuk melakukan perilaku-perilaku hedonis (Rook \& Fisher, 1995). Perilaku impulsif yang dilakukan oleh konsumen di sisi lain justru dapat memberikan dampak positif bagi pihak retailer dikarenakan pembelian secara impulsif maka akan menimbulkan kenaikan angka penjualan produk yang ditawarkan oleh pihak retailer (Cole \& Clow, 2011).

Muruganantham dan Bhakat (2013) menyatakan terdapat empat jenis faktor penyebab terjadinya impulsive buying yang dilakukan oleh konsumen, yaitu faktor eksternal (karakteristik toko, sales promotions, karyawan, lingkungan toko dan lain-lain), faktor internal (impulsiveness, enjoyment, hedonism, fashion, self-identity, dan lain-lain), faktor situasional dan product related factors (waktu, uang, karakteristik produk, produk fashion, dan produk baru), serta faktor demografi dan sosio-kultural (umur, jenis kelamin, pendapatan, edukasi, budaya, dan sosio-ekonomi). Salah satu faktor yang dapat menyebabkan terjadinya perilaku impulsive buying pada konsumen adalah lingkungan toko atau store atmosphere dan brand image. Store atmosphere adalah semua hal yang mencakup fasilitas fisik yang dimana pihak toko memberikan layanan-layanan yang di berikan kepada konsumen (Baker, 1986). Sherman, dkk. (1997) menyatakan bahwa store atmosphere adalah stimulus atau rangsangan didalam toko yang diberikan oleh pihak toko yang dapat memberikan pengaruh pada kondisi internal individu. Store atmosphere dijadikan alat oleh pihak toko sebagai strategi marketing mereka guna meningkatkan penjualan produk-produk yang ditawarkan kepada konsumen. Produk yang ada di dalam toko, seperti poster iklan, penempatan produk di dalam toko, musik, aroma, kebersihan toko, dan lingkungan toko adalah faktor-faktor didalam toko yang dapat mempengaruhi perilaku belanja pada konsumen (Mariri \& Chipunza, 2009).

Brand image menjadi faktor kedua yang mempengaruhi adanya pembelian yang tidak direncanakan atau impulsive buying. Pada era saat ini konsumen dapat memilih dari sejumlah brand fashion asing maupun domestik yang disukai untuk melakukan pembelajaan dikarenakan sudah banyak macam perusahaan di dunia bisnis fashion. Brand dari perusahaan fashion di seluruh dunia yang menjamur menimbulkan pertanyaan baru apakah konsumen pasar memiliki persepsi mengenai brand-brand fashion secara berbeda dan bagaimana persepsi mengenai brand image suatu perusahaan bisnis fashion mempengaruhi perilaku pembelian konsumen di dunia. Brand mencerminkan citra positif dari tiap perusahaan yang menjual produk ataupun jasa untuk konsumen pasar. Brand image membantu konsumen membentuk persepsi positif maupun negatif mengenai produk atau jasa yang ditawarkan oleh perusahaan. Brand image adalah pengetahuan individu akan suatu brand yang mempengaruhi sikap konsumen terhadap brand tersebut (Hariri \& Vazifehdust, 2011). Brand image juga didefinisikan 
sebagai persepsi individu tentang suatu brand yang tercermin dari asosiasi brand yang ada di memori konsumen. Asosiasi brand adalah serangkaian informasi yang berhubungan dengan suatu brand di dalam memori individu dan mengandung arti dari suatu brand bagi individu (Keller, 1993).

Brand image memiliki fungsi penting dalam mempelopori keunggulan dari produk tiap perusahaan. Dengan brand image suatu produk sangat kuat di pasaran dapat memimpin produk-produk yang ada pada pasar. Fungsi lainnya adalah brand image sebagai nilai dari perusahaan sebagai hasil invetasi dari biaya iklan dan peningkatan kualitas produk ataupun jasa. Perusahaan dapat menggunakan nilai yang disimpan sebagai modal untuk mengubah ide pemasaran strategis menjadi keunggulan kompetitif untuk jangka panjang (Wijaya, 2013). Hariri dan Vazifehdust (2011) membagi brand image menjadi tiga dimensi yaitu functional image (image dari suatu brand yang dilihat dari fungsi produknya), affective image (image dari suatu brand yang dilihat dari sikap terhadap brand), dan reputation (image dari suatu brand yang dilihat dari reputasi merek). Tiga dimensi yang telah disebutkan diatas memberikan konstribusi positif untuk menciptakan pengalaman positif yang mengarahkan konsumen untuk menjadi penggemar suatu brand produk yang ditawarkan di pasaran.

Hasil penelitian dahulu menunjukkan penyebab yang memunculkan adanya dorongan yang kuat untuk melakukan perilaku impulsif adalah seperti atmosfer dan tampilan toko (Abratt \& Goodey, 1990). Hasil penelitian terdahulu juga menyatakan bahwa adanya hubungan yang signifikan antara store atmosphere dengan perilaku impulsive buying. Hal ini dapat dikatakan bahwa store atmosphere dengan perilaku impulsive buying memiliki hubungan yang positif (Akram, Hashim, Khan, \& Rasheed, 2016). Perbedaan hasil penelitian yang telah diteliti oleh Setiyono (2015) yang menunjukkan hasil yang sama yaitu store atmosphere tidak memiliki pengaruh terhadap perilaku impulsive buying pada konsumen. Hasil tersebut juga menunjukkan bahwa terdapat perbedaan hasil penelitian terdahulu terkait dengan pengaruh store atmosphere dengan impulsive buying.

Penelitian yang telah dilakukan oleh Sari (2020) menunjukkan bahwa brand image memiliki pengaruh positif dan signifikan terhadap impulse buying. Hasil penelitian Cahyani (2019) menunjukkan bahwa baik secara simultan maupun parsial variabel brand image berpengaruh terhadap keputusan pembelian tidak terencana. Hasil berbeda ditunjukkan oleh penelitian yang dilakukan oleh Alfaiz (2018) yaitu brand image tidak berpengaruh terhadap perilaku impulsive buying. Hal inilah yang menjadi acuan peneliti untuk melakukan penelitian lebih lanjut mengenai pengaruh store atmosphere dan brand image terhadap impulsive buying. Berdasarkan pada tujuan tersebut, peneliti mengajukan hipotesis pada penelitian ini, yaitu:

$\mathrm{H}_{\mathrm{a} 1} \quad$ : Terdapat pengaruh store atmosphere terhadap impulsive buying secara parsial.

$\mathrm{H}_{\mathrm{a} 2} \quad$ : Terdapat pengaruh brand image terhadap impulsive buying secara parsial.

$\mathrm{H}_{\mathrm{a} 3} \quad$ : Terdapat pengaruh store atmosphere dan brand image terhadap impulsive buying secara simultan.

\section{Desain Penelitian}

\section{METODE}

Tipe penelitian yang peneliti gunakan adalah penelitian kuantitatif. Penelitian kuantitatif adalah penelitian yang berawal dari suatu teori yang akan menghasilkan analisis berupa data-data numerik kemudian diolah menggunakan metode statistika dan dilakukan pengujian terhadap hipotesis yang di ajukan. Pendekatan kuantitatif menitikberatkan hasil analisisnya pada data-data numerik dan diolah dengan metode statistika, serta dilakukan pada dalam rangka pengujian hipotesis (Neuman, 2013). Peneliti mengkatagorikan penelitian ini sebagai penelitian eksplanatori. Penelitian yang bertujuan 
untuk memperdalam, mengembangkan, dan menguji suatu konstruk atau teori, di mana penelitian ini dilakukan yang memiliki tujuan untuk mengetahui pengaruh store atmosphere dan brand image terhadap impulsive buying (pembelian impulsif) pada konsumen retail fashion brand X di Surabaya.

\section{Partisipan}

Pada penelitian ini populasi yang digunakan adalah konsumen yang melakukan pembelian produk pada retail fashion. Produk fashion pada penelitian ini terdiri dari pakaian atasan, pakaian bawahan, aksesoris, sepatu, dan tas. Untuk kriteria partisipan pada penelitian ini adalah laki-laki atau perempuan yang berusia 17 hingga 45 tahun yang tinggal di Surabaya dan pernah membeli produk fashion brand tertentu dalam 1 tahun terakhir di gerai atau toko offline di Surabaya. Pada penelitian ini, peneliti menggunakan metode sampling kebetulan atau purposive sampling. Purposive sampling adalah teknik pengambilan sampel sumber data dengan menyertakan pertimbangan tertentu (Sugiyono, 2019). Dalam penelitian ini, peneliti akan membagikan kuesioner penelitian kepada partisipan secara kebetulan hingga mencukupi jumlah partisipan yang diinginkan. Dalam menentukan kuota sampling pada penelitian ini, peneliti menggunakan perangkat lunak $G^{*}$ Power 3.1.9.4 dengan effect size sebesar 0.15 dengan signifikasi sebesar 0.05 dengan power 0.95 . Melalui ketentuan tersebut, didapatkan sampel minimum penelitian sebanyak 107 partisipan.

\section{Melaporkan data deskriptif}

Pada penelitian ini terdapat 130 partisipan yang ikut dalam penelitian. Data demografi menunjukkan partisipan didominasi oleh perempuan sebanyak 77 orang (59,2\%) sedangkan laki-laki sebanyak 53 orang $(40,8 \%)$. Usia partisipan berada pada rentang usia 21-25 tahun memiliki persentase tertinggi $62,4 \%$ atau sebanyak 81 orang. Pada data demografi pendidikan terakhir, partisipan dengan pendidikan terakhir sarjana adalah partisipan yang memiliki persentase tertinggi 54,6\% atau sebanyak 71 orang. Pada data demografi pekerjaan partisipan, mayoritas partisipan adalah pelajar atau mahasiswa dengan persentase $36,9 \%$ atau 48 orang. Pada data demografi penghasilan, penghasilan dengan rentang kurang dari Rp2.000.000 memiliki jumlah partisipan terbanyak yaitu 62 orang atau 47,7\%. Pada data demografi frekuensi berbelanja, sebanyak 93 orang atau 71,5\% melakukan pembelanjaan satu kali dalam sebulan.

\section{Pengukuran}

Peneliti menggunakan alat pengumpul data berupa kuesioner dikarenakan partisipan adalah orang yang paling mengerti mengenai keadaan diri mereka, pernyataan dari partisipan yang diberikan kepada peneliti adalah benar dan dapat dipercaya, dan interpretasi partisipan terhadap pernyataan yang diajukan kepadanya sama dengan apa yang peneliti maksud. Pengambilan data dilakukan secara online karena individu akan cenderung memiliki social desirability yang rendah ketika mengisi kuesioner melalui internet (Lim, 2002). Skala yang digunakan dalam kuesioner pengukuran impulsive buying, store atmosphere dan brand image menggunakan skala likert tujuh respon jawaban terhadap aitem yang diberikan. Alat ukur yang digunakan peneliti dalam penelitian ini merupakan alat ukur translasi, maka sebelum dilakukan penyebaran kuesioner kepada partisipan sampel penelitian, peneliti melakukan beberapa persiapan, seperti:

1. Menerjemahkan aitem dari bahasa Inggris ke bahasa Indonesia, dengan meminta bantuan kepada ahli mengenai teori yang akan digunakan sebagai alat ukur

2. Penilaian dan penyesuaian istilah oleh beberapa professional judgement

3. Penyempurnaan bahasa pada aitem yang digunakan

Alat ukur yang digunakan dalam penelitian ini adalah alat ukur impulsive buying yang dikembangkan oleh (Rook \& Fisher, 1995) Pemilihan alat ukur impulsive buying digunakan merupakan alat ukur yang 
bersifat unidimensi dimana alat ukur ini tidak membagi konstruk dalam beberapa dimensi, melainkan hanya memiliki satu dimensi yaitu impulsive buying. Alat ukur ini merupakan skala yang menggunakan model skala likert yang memiliki tujuh alternatif jawaban, yaitu sangat tidak setuju $=1$, tidak setuju $=2$, sedikit tidak setuju $=3$, netral $=4$, sedikit setuju $=5$, setuju $=6$, dan sangat setuju $=7$. Kemudian alat ukur Store atmosphere yang dikembangkan oleh (Krumpelmann, 2018) sebagai dasar penyusunan alat ukur. Pemilihan alat ukur store atmosphere digunakan merupakan alat ukur yang bersifat unidimensi dimana alat ukur ini tidak membagi konstruk dalam beberapa dimensi, melainkan hanya memiliki satu dimensi yaitu store atmosphere. Alat ukur ini merupakan skala yang menggunakan model skala likert yang memiliki tujuh alternatif jawaban, yaitu sangat tidak menyenangkan $=1$, tidak menyenangkan $=2$, sedikit tidak menyenangkan $=3$, netral $=4$, sedikit menyenangkan $=5$, menyenangkan $=6$, dan sangat menyenangkan $=7$.

Pada brand image alat ukur yang digunakan adalah yang dikembangkan oleh (Hariri \& Vazifehdust, 2011). Pemilihan alat ukur brand image digunakan merupakan alat ukur yang bersifat multidimensi dimana alat ukur ini membagi konstruk dalam beberapa dimensi. Alat ukur ini merupakan skala yang menggunakan model skala likert yang memiliki tujuh alternatif jawaban, yaitu sangat tidak setuju $=1$, tidak setuju $=2$, sedikit tidak setuju $=3$, netral $=4$, sedikit setuju $=5$, setuju $=6$, dan sangat setuju $=7$.

Pada penelitian ini, uji validitas yang digunakan adalah dengan bantuan professional judgement. Pada alat ukur impulsive buying yang dikembangkan oleh (Rook \& Fisher, 1995) alat ukur store atmosphere yang dikembangkan oleh (Krumpelmann, 2018), dan alat ukur brand image yang dikembangkan oleh (Hariri \& Vazifehdust, 2011), peneliti melakukan translasi dan melakukan uji validitas melalui professional judgement agar tidak merubah makna alat ukur aslinya. Professional judgement yang dilakukan terdiri dari 3 ahli, yaitu Ibu Rosidah (finance manager), Bapak Malik Purnomo (Owner toko baju brand X di Surabaya), dan Bapak Hendhy Setiawan (Designer dan pemilik toko baju di Surabaya).

Peneliti menggunakan uji reliabilitas terpakai, yang dapat diartikan pelaksanaan uji reliabilitas dilakukan setelah proses pengambilan data dilakukan (Azwar S. , 2011). Pada penelitian ini, pengukuran reliabilitas alat ukur akan dilakukan pada 130 partisipan dengan menggunakan Cronbach's Alpha dengan menggunakan program IBM SPSS Statistic 22 for Windows. Kemudian, nilai koefisien reliabilitas yang telah didapatkan dapat dianalisis melalui derajat reliabilitas yang dikemukakan oleh (Guilford \& Benjamin, 1956).

\section{Melaporkan reliabilitas alat ukur}

Alat ukur yang digunakan peneliti untuk mengukur pembelian impulsif menggunakan alat ukur impulsive buying yang di dikembangkan oleh (Rook \& Fisher, 1995) terdiri dari 9 aitem dengan 7 pilihan jawaban (sangat tidak setuju $=1$, tidak setuju $=2$, sedikit tidak setuju $=3$, netral $=4$, sedikit setuju $=5$, setuju $=6$, dan sangat setuju $=7$ ). Diketahui bahwa hasil uji reliabilitas pada skala impulsive buying 0,694. Mengacu pada derajat reliabilitas (Guilford \& Benjamin, 1956) menyatakan bahwa reliabilitas alat ukur impulsive buying memiliki derajat reliabilitas sedang. Hal ini mengindikasi bahwa alat ukur tersebut reliable untuk mengukur impulsive buying.

Alat ukur store atmosphere ukur yang digunakan peneliti dikembangkan (Krumpelmann, 2018) terdiri dari 11 aitem dengan 7 pilihan jawaban (sangat tidak menyenangkan $=1$, tidak menyenangkan $=2$, sedikit tidak menyenangkan $=3$, netral $=4$, sedikit menyenangkan $=5$, menyenangkan $=6$, dan sangat menyenangkan = 7). Diketahui bahwa hasil uji reliabilitas pada skala store atmosphere 0,885. Mengacu pada derajat reliabilitas (Guilford \& Benjamin, 1956) menyatakan bahwa reliabilitas alat ukur store 
atmosphere memiliki derajat reliabilitas tinggi. Hal ini mengindikasi bahwa alat ukur tersebut reliabel untuk mengukur store atmosphere.

Alat ukur brand image yang digunakan adalah alat ukur yang dikembangkan oleh (Hariri \& Vazifehdust, 2011) terdiri dari 8 aitem dengan 7 pilihan jawaban (sangat tidak setuju $=1$, tidak setuju $=2$, sedikit tidak setuju $=3$, netral $=4$, sedikit setuju $=5$, setuju $=6$, dan sangat setuju $=7$.). Diketahui bahwa hasil uji reliabilitas pada skala brand image dilakukan per dimensi. Dimensi functional image menghasilkan Cronbach's Alpha sebesar 0,629 yang dapat didefinisikan memiliki derajat reliabilitas sedang. Kemudian pada dimensi affective image menghasilkan Cronbach's Alpha sebesar 0,807 yang dapat didefinisikan memiliki derajat reliabilitas tinggi, dan untuk dimensi reputation menghasilkan Cronbach's Alpha sebesar 0,670 yang dapat didefinisikan memiliki derajat reliabilitas sedang. Hal ini mengindikasi bahwa alat ukur tersebut reliable untuk mengukur brand image.

\section{HASIL PENELITIAN}

\section{Analisis Statistik Deskriptif}

Pada penelitian terdapat 130 partisipan yang menjadi partisipan penelitian ini. Nilai mean atau ratarata yang dimiliki partisipan pada variabel store atmosphere adalah 60,41. Kemudian variabel brand image memiliki nilai rata-rata sebesar 41,56, dan variabel impulsive buying memiliki nilai rata-rata 33,59. Tabel di atas juga menunjukkan nilai standar deviasi (SD). Tabel di atas menunjukkan bahwa nilai standar deviasi yang dimiliki setiap variabel cenderung lebih kecil jika dibandingkan dengan nilai mean variabel tersebut. Hal ini mengindikasi bahwa penyimpangan data pada setiap variabel penelitian cenderung kecil. Pada penelitian ini menunjukkan nilai skewness dan kurtosis yang didapatkan oleh tiga variabel penelitian. Nilai skewness yang didapatkan variabel store atmosphere adalah -0,409 dan nilai kurtosis yang didapatkan adalah -0,674 serta nilai skewness yang didapatkan variabel brand image 0,150 dan nilai kurtosis yang didapatkan adalah -0,959. Hal ini menunjukkan bahwa distribusi data berada di sebelah kanan dan berada di titik ekstrim atau mendatar. Nilai skewness yang didapatkan variabel impulsive buying adalah 0,135 dan nilai kurtosis yang didapatkan adalah -0,544. Hal ini menunjukkan bahwa distribusi data variabel impulsive buying berada di sebelah kiri dan cenderung menyebar.

\section{Analisis Hasil Penelitian}

Uji normalitas dilakukan pada 130 partisipan. Hasil signifikansi yang didapatkan sebesar 0,192. Hal ini menunjukkan bahwa data yang diperoleh memiliki distribusi yang normal karena signifikansi yang didapatkan lebih dari 0,05. Kemudian, dilakukan uji linieritas dan dari hasil analisis didapatkan bahwa nilai signifikansi variabel store atmosphere dan brand image lebih dari 0,05, dapat dikatakan bahwa data yang didapatkan linier.

Hasil uji glejser untuk memeriksa adanya heterokedastisitas pada penelitian ini menunjukkan bahwa, nilai signifikansi yang didapatkan dari variabel yang ada pada penelitian ini lebih dari 0,05 yang berarti tidak terjadi heterokedastisitas pada data.

Hasil korelasi koefisien yang didapat, menunjukkan hubungan variabel store atmosphere dengan impulsive buying signifikan ke arah positif dikarenakan nilai yang didapat adalah positif 1,000. Hal ini mengindikasi bahwa semakin tinggi nilai store atmosphere yang diperoleh, maka perilaku impulsive buying juga akan semakin meningkat. Begitu pula sebaliknya. Namun variabel store atmosphere dengan impulsive buying tidak memiliki hubungan signifikan karena nilai signifikansi yang didapatkan lebih dari 
0,05 ( $p>0,05$ ). Nilai koefisien korelasi menujukkan bahwa kuat lemahnya hubungan antar kedua variabel adalah angka 0,155 .

Hubungan variabel brand image dengan impulsive buying signifikan ke arah positif. Hal ini mengindikasi bahwa semakin tinggi nilai brand image, maka perilaku impulsive buying juga akan semakin meningkat. Begitu pula sebaliknya. Kuat lemahnya hubungan antar kedua variabel menunjukkan angka 0,240 berdasarkan koefisien korelasi dengan nilai signifikansi yang didapatkan adalah 0,006. Hal ini mengindikasi bahwa hubungan antara brand image dengan impulsive buying signifikan, karena signifikansi yang didapatkan kurang dari 0,05 $(\mathrm{p}<0,05)$.

Hasil analisis menunjukkan bahwa nilai $\mathrm{R}=0,249$. Nilai tersebut merupakan korelasi antara variabel store atmosphere dan brand image terhadap impulsive buying. Pallant (2011) memiliki pedoman dalam menginterpretasikan besar nilai $R$ yaitu 0,10-0,29 lemah; 0,30-0,49 sedang; dan 0,50-1,0 kuat. Hal tersebut menunjukkan bahwa terdapat hubungan lemah antara store atmosphere dan brand image terhadap impulsive buying. Berdasarkan hasil analisis, diketahui nilai koefisien determinasi atau $\mathrm{R}^{2}=$ 0,062. Besar angka koefisien determinasi adalah 0,062 atau sama dengan 6,2\%. Angka tersebut mengandung arti bahwa variabel store atmosphere dan brand image secara simultan berpengaruh terhadap impulsive buying sebesar 6,2\%. Sedangkan 93,8\% lainnya dipengaruhi oleh variabel lain yang tidak diteliti dalam penelitian ini.

Pada penelitian ini uji validitas model melalui uji anova dengan nilai F-regression sebesar 4,188 dan sig $0,017<0,05$ atau $\mathrm{H}_{0}$ ditolak dan $\mathrm{H}_{\mathrm{a}}$ diterima. Hal tersebut berarti ada pengaruh store atmosphere dan brand image secara simultan terhadap impulsive buying.

Berdasarkan hasil analisis diketahui bahwa nilai signifikansi Variabel store atmosphere adalah sebesar 0,439. Karena nilai sig. 0,439 > 0,05, maka dapat disimpulkan bahwa $\mathrm{H}_{\mathrm{a} 1}$ ditolak dan $\mathrm{H}_{01}$ diterima. Artinya tidak ada pengaruh store atmosphere terhadap impulsive buying secara parsial. Sedangkan untuk variabel brand image, nilai signifikansi yang didapat adalah sebesar 0,025. Karena nilai signifikansi $0,025<0,05$, maka dapat disimpulkan bahwa $\mathrm{H}_{\mathrm{a} 2}$ diterima $\mathrm{H}_{02}$ ditolak. Artinya terdapat pengaruh brand image terhadap impulsive buying secara parsial.

\section{DISKUSI}

Rook (1987) mendefinisikan impulsive buying yakni sebuah kondisi ketika konsumen mengalami keinginan untuk membeli barang yang tiba-tiba, kuat, dan terus-menerus. Rook mencirikan pembelian impulsif sebagai reaksi konsumen yang tidak disengaja dan tidak reflektif, yang terjadi secara tiba-tiba setelah mendapatkan rangsangan di dalam toko. Pembelian impulsif adalah aspek yang menarik dari perilaku konsumen bagi perusahaan dikarena konsumen dapat melakukan pembelian lebih banyak daripada yang mereka rencanakan sebelumnya. Konsumen adalah sumber pendapatan dan keuntungan bagi perusahaan sehingga sangat penting bagi pemasar untuk memahami perilaku konsumen (Hussain \& Ali, 2015).

Hasil analisis yang telah dilakukan menunjukkan bahwa terdapat pengaruh yang signifikan antara variabel store atmosphere dan brand image secara simultan terhadap impulsive buying dikarenakan hasil signifikansi menunjukan hasil 0,017 atau kurang dari 0,05 atau $\mathrm{H}_{03}$ ditolak dan $\mathrm{H}_{\mathrm{a} 3}$ diterima. Hasil analisis regresi linier berganda juga menunjukkan bahwa terdapat hubungan lemah antara store atmosphere dan brand image terhadap impulsive buying. Hal ini dikarenakan hasil nilai R square atau nilai koefisien determinasi $\left(R^{2}\right)$ yaitu 0,062 atau $6,2 \%$ atau dapat dikatakan juga bahwa terdapat faktor lain yang tidak diteliti dalam penelitian ini sebesar 93,8\% yang dapat mempengaruhi impulsive buying. 
Hasil penelitian yang peneliti lakukan belum ada yang memiliki hasil yang sama dengan peneliti sebelumnya, yang menunjukkan bahwa secara simultan store atmosphere dan brand image berpengaruh terhadap impulsive buying.

Berdasarkan hasil regresi secara parsial menunjukkan bahwa brand image memiliki pengaruh signifikan sebesar 0,025 terhadap impulsive buying. Dapat diartikan bahwa $\mathrm{H}_{\mathrm{a} 2}$ penelitian ini diterima. Didukung oleh hasil penelitian dari Wulansari \& Seminari (2015) secara parsial brand image berpengaruh secara signifikan terhadap impulsive buying. Brand image memiliki peranan penting dalam menarik minat konsumen pada produk yang ditawarkan. Dampak brand image yang dibuat oleh pihak retail fashion akan sangat kuat apabila relevan dengan apa yang konsumen inginkan atas suatu produk (Pullig, 2008).

Hasil penelitian mengenai pengaruh store atmosphere dengan impulsive buying yang didapatkan melalui penelitian ini menarik untuk dibahas. Setelah dilakukan uji korelasi menggunakan Pearson's, penelitian ini menemukan bahwa store atmosphere secara parsial tidak memiliki pengaruh terhadap impulsive buying yang signifikan. Hal ini didukung oleh penelitian yang telah dilakukan Murnawati dan Zulia (2018) yang menunjukkan bahwa store atmosphere tidak memiliki pengaruh signifikan terhadap impulsive buying.

Dari hasil analisis di atas, menunjukkan bahwa store atmosphere tidak memiliki pengaruh yang signifikan terhadap impulsive buying secara parsial, tetapi store atmosphere dan brand image secara simultan memiliki pengaruh yang signifikan terhadap impulsive buying. Fungsi dari brand image disini adalah sebagai stimuli konsumen untuk masuk ke dalam toko. Ketika konsumen telah masuk ke dalam toko, store atmosphere berperan penting dalam menciptakaan suasana bagi konsumen pada saat didalam toko. Dimana nantinya diharapkan konsumen tersebut membeli produk yang ditawarkan pada toko yang dikunjungi (Fuad, 2010). Saat ini, konsumen terpaku pada nama brandnya terlebih dahulu setelah itu baru melihat produknya. Reputasi suatu brand pada persepsi konsumen sangatlah penting. Hal ini dikarenakan brand image berperan penting dalam menarik minat konsumen akan produk yang ditawarkan. Apabila pihak toko telah memiliki image yang baik atau reputasi yang baik pada konsumen, maka hal ini dapat dianggap menjadi salah satu faktor naiknya perilaku impulsif.

Peneliti juga melakukan uji analisis tambahan pada hubungan penghasilan terhadap impulsive buying. Hubungan penghasilan dengan impulsive buying ke arah positif. Hal ini mengindikasi bahwa semakin tinggi penghasilan seseorang, maka perilaku impulsive buying juga akan semakin tinggi. Nilai signifikansi $(p=0,069)$ lebih besar dari 0,05 sehingga dapat diartikan bahwa kedua variabel berhubungan secara tidak signifikan. Hal ini menjadi indikasi bahwa tinggi rendahnya penghasilan yang dimiliki konsumen tidak berhubungan dengan tinggi rendahnya perilaku impulsive buying terjadi.

\section{SIMPULAN}

Penelitian ini bertujuan untuk mengetahui lebih lanjut pengaruh store atmosphere dan brand image terhadap impulsive buying pada konsumen retail fashion brand X. Setelah melakukan analisis data, penelitian ini mendapatkan hasil bahwa tidak terdapat pengaruh secara parsial variabel store atmosphere terhadap impulsive buying. Kemudian hasil analisis data menunjukkan pengaruh variabel brand image dengan impulsive buying signifikan ke arah positif. Hal ini mengindikasikan bahwa semakin tinggi nilai brand image, maka perilaku impulsive buying juga akan semakin meningkat. Namun, hasil analisis regresi bersama menunjukkan bahwa terdapat pengaruh yang signifikan antara variabel store atmosphere dan brand image secara simultan terhadap impulsive buying. Kemudian hasil analisis tambahan pada penelitian ini mengenai hubungan penghasilan terhadap impulsive buying adalah 
memiliki hubungan kearah positif namun tidak signifikan. Hal ini dapat diartikan bahwa penghasilan yang didapatkan konsumen tidak berhubungan dengan munculnya perilaku impulsive buying.

Pada penelitian ini masih terdapat kekurangan dan kelemahan, oleh karena itu saran yang dapat penulis berikan kepada peneliti selanjutnya yang akan meneliti dengan tema serupa agar dapat memperbaiki kekurangan dan kelemahan dalam penelitian ini. Bagi penelitian selanjutnya dapat memperluas kajian sampel partisipan, pada penggunaan objek pada penelitian ini dapat mengembangkan pada objek lainnya atau pada sektor bidang selain fashion. Peneliti selanjutnya juga dapat melakukan penelitian lebih lanjut terhadap faktor-faktor lainnya yang dapat mempengaruhi perilaku impulsive buying. Kemudian saran untuk perusahaan fashion adalah menentukan strategi yang cocok atau relevan dengan permintaan konsumen untuk menguatkan brand image produk perusahaan. Kemudian diikuti dengan peningkatan store atmosphere pada toko yang dimiliki perusahaan guna mendukung munculnya perilaku pembelian yang tidak direncanakan pada konsumen.

\section{UCAPAN TERIMAKASIH}

Seluruh pihak yang namanya tidak dapat disebutkan satu per satu. Terima kasih telah hadir, membantu penulis, memberi pengalaman serta pelajaran dalam kehidupan penulis.

\section{DEKLARASI POTENSI TERJADINYA KONFLIK KEPENTINGAN}

Annisa Savira Alifia dan Cholichul Hadi sebagai penulis tidak bekerja, menjadi konsultan, memiliki saham, atau menerima dana dari perusahaan atau organisasi manapun yang mungkin akan mengambil untung dari diterbitkannya naskah ini.

\section{PUSTAKA ACUAN}

Abratt, R., \& Goodey, S. D. (1990). Unplanned buying in-store stimuli in supermarkets. Managerial and Decision Economics, 11, 111-121.

Akram, U., Hashim, M., Khan, K. M., \& Rasheed, S. (2016). Impact of store atmosphere on impulse buying behavior: Moderating effect of demographic variables. International Journal of u- and e-Service, Science and Technology, Vol.9, No. 7, pp.43-60.

Alfaiz, M. D. (2018). Faktor Yang Mempengaruhi Impulsive Buying Konsumen Pands Yogyakarta Dalam Perspektif Perilaku Konsumsi Islami. Yogyakarta: Universitas Islam Indonesia.

Azwar, S. (2011). Metode Penelitian. Yogyakarta: Pustaka Pelajar.

Baker, J. (1986). The role of the environment in marketing services: The consumer perspective. Texas Christian University, 79-84.

Bayley, G., \& Nancarrow, C. (1998). Impulse purchasing: a qualitative exploration of the phenomenon. Qualitative Market Research: An International Journal, Volume 1, pp. 99-168. 
Beatty, S. E., \& Ferrell, M. E. (1998). Impule Buying: Modeling its precursors. Journal of Retailing,. Journal of Retailing, 169-191.

Cahyani, R. (2019). Pengaruh potongan harga, Citra merek dan tampilan dalam toko terhadap keputusan pembelian tidak terencana pada Matahari Departement Store Pakuwon Trade Center di Surabaya. H Social Sciences, 1-70.

CNN. (2015, November 2). www.cnnindonesia.com. Dipetik April 19, 2021, dari (https://www.cnnindonesia.com/ekonomi/20151102182452-92-88999/generasi-millenialri-paling-impulsif-belanja-barang-mewah)

Cole, H. S., \& Clow, K. E. (2011). A Model Development of Retail Patronage Loyalty. Journal of Business Studies Quarterly, Vol. 2, No. 2, pp. 1-16.

Dittmar, H., \& Drury, J. (2000). Self-image is it in the bag? A qualitative comparison between 'ordinary' and 'excessive' consumers. Journal of Economic Psychology, 59: 202-216.

Fuad, M. (2010). Store Atmosphere dan Perilaku Pembelian Konsumen Di Toko Buku Gramedia Malang. Malang: Universitas Gajayana.

Guilford, J. P., \& Benjamin, F. (1956). Fundamental Statistics in Psychology and Education. New York: Mc Graw-Hill Book Company, Ltd.

Hariri, M., \& Vazifehdust, H. (2011). How does Brand Extension Affect Brand Image? International Conference on Business and Economics, 104-109.

Hussain, R., \& Ali, M. (2015). Effect of Store Atmosphere on Consumer Purchase Intention. International Journal of Marketing Studie, 35-43.

Keller, K. L. (1993). Conceptualizing, Measuring, and Managing Customer-Based Brand Equity. Journal of Marketing, 1-22.

Krumpelmann, L. (2018). The influence of store environment on customer's satisfaction and purchase behavior. Netherlands: Wageningen University and Research.

Kusuma, A. P. (2017). Pengaruh faktor stimulus internal dan eksternal konsumen di beberapa mall di indonesia terhadap kecenderungan perilaku pembelian impulsif. Makassar: Universitas Muslim Indonesia.

Lim, V. K. (2002). The IT Way of Loafing on the Job: Cyberloafing, Neutralizing and Organizational Justice. Journal of Organizational Behavior.

Mariri, T., \& Chipunza, C. (2009). In-store shopping environment and impulsive buying. African Journal of Marketing Management, Vol. 1(4) pp. 102-108.

Mehta, N. T., \& Sharma, A. (2013). Introduction To The Fashion Industry: Student Handbokk Class-XI. India: CBSE. 
Murnawati, \& Zulia, K. (2018). Store Environmental Atmosphere on Giant Hypermarket Pekanbaru: Do Effect on Consumers Positive Emotion and Impulse? IOP Conf. Series: Earth and Environmental Science, 1-6.

Muruganantham, G., \& Bhakat, S. R. (2013). A Review of Impulse Buying Behavior. International Journal of Marketing Studies, Vol. 5, No. 3; pp. 149-160.

Neuman, W. L. (2013). Metodologi Penelitian Sosial Pendekatan Kualitatif dan Kuantitatif Edisi 7. Jakarta: Indeks.

Pallant, J. (2011). SPSS Survival Manual: A Step by Step Guide to Data Analysis using SPSS 4th Edition. Crows Nest: Allen \& Unwin.

Pullig, C. (2008). What is Brand Equity and What Does the Branding Concept Mean to You? Keller Center Research Report, 1-4.

Ramadhan, A. (2017). Produk Fashion pada Anak sebagai Kelengkapan Tubuh (Studi Kasus: Anak yang Bekerja). Jurnal Penelitian Internal 2017/2018, 1-33.

Rook, D. W. (1987). The Buying Impulse. Journal of Consumer Research, 14(2), 189-199.

Rook, D. W., \& Fisher, R. J. (1995). Normative Influences On Impulsive Buying Behavior. Journal of Consumer Research, 22, 305-312.

Sari, A. K. (2020). Pengaruh Discount, Brand Image, dan Store Atmosphere terhadap Impulse Buying. Academica: Journal of Multidisciplinary Studies, 199-211.

Setiyono, A. D. (2015). Analisis Pengaruh Promosi Penjualan Dan Store Atmosphere Terhadap Shopping Emotion Dan Dampaknya Terhadap Impulse Buying. Jakarta: Fakultas Ekonomi dan Bisnis Universitas Islam Negeri Syarif Hidayatullah.

Sherman, E., Mathur, A., \& Smith, R. B. (1997). Store Environment and Consumer Purchase Behavior: Mediating Role of Consumer Emotions. Psychology \& Marketing, Vol. 14(4):361-378.

Stern, H. (1962). The significance of impulse buying today. Journal of marketing, 26, 59-62.

Sugiyono. (2019). Metode Penelitian Kuantitatif Kualitatif dan R\&D. Jakarta: Alfabeta.

Verplanken, B., \& Aarts, H. (1999). Habit, attitude, and planned behaviour: is habit an empty construct, or an interesting case of automaticity? European Review of Social Psychology, 10: 101-133.

Wijaya, B. S. (2013). Dimensions of Brand Image: A Conceptual Review from the Perspective of Brand Communication. European Journal of Business and Management, 55-65.

Wulansari, N. R., \& Seminari, N. (2015). Analisis Pengaruh Store Environment dan Brand Image terhadap Impulse Buying Pada Delta Dewata Supermarket. E-Jurnal Manajemen Unud, 2478-2490. 